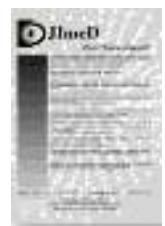

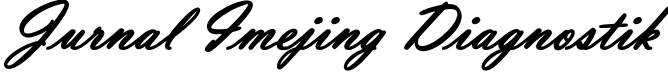

e-ISSN 2621-7457, p-ISSN 2356-301X

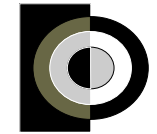

http://ejournal.poltekkessmg.ac.id/ojs/index.php/jimed/index

\title{
Deteksi Tepi pada Citra Rontgen Penyakit COVID-19 Menggunakan Metode Sobel
}

\author{
Muhammad Ghozali ${ }^{1}$, Heni Sumarti ${ }^{2}$ \\ 12 Universitas Islam Negeri Walisongo Semarang, Indonesia
}

Corresponding author: Muhammad Ghozali

E-mail: muhammadghozali_1708026010@student.walisongo.ac.id

Received: June $16^{\text {th }}, 2020$; Revised: June $23^{\text {rd }}$, 2020; Accepted: June $30^{\text {th }}, 2020$

\begin{abstract}
Background: Coronavirus Disease 2019 (COVID-19) discovered at the end of 2019 occasioned by coronavirus 2 (SARS-CoV-2) causing severe acute respiratory syndrome and expanded globally so that World Health Organization (WHO) declare a global pandemic. There was a delay of socialization and delivering information to society about this disease. The doctors did a method to detect COVID-19 by reading the correct $\mathrm{X}$-ray images of patients who affected by a coronavirus.

Methods: With advances in the field of computers in the application of image processing techniques method of this research use application to get better digital image results for COVID-19 X-ray images, so make it easier to analyze the X-ray images. There are 13 samples of X-ray images that are processed through the clean the stage with high-pass filtering, then segmented with thresholding technique in the lung area, then the edge detection method is used to mark the area that makes the image detail.

Results: The result of this detection form the pattern of objects and regions of the spread of coronavirus, then there is a limit on the image looks clear enough, with the Sobel method producing white pixels that are so visible as well.

Conclusions: This study to make a simulation of x-ray thorax COVID-19 and know the region of virus infection using Sobel method with thresholding technique that can see the spread of coronavirus and shown that edge detection use Sobel method as one of diagnosing for COVID-19 disease.
\end{abstract}

Keyword : x-ray image; COVID-19; segmentation; edge detection; sobel method.

\section{Pendahuluan}

Sejak Desember 2019 ada beberapa kasus pneumonia dengan penyebab yang tak diketahui telah muncul di Wuhan, China. Melalui pemeriksaan seorang pasien bahwa terdapat sebuah coronavirus baru dari sel epitel saluran nafas manusia yang disebut SARS-CoV-2 menjadi asal muasal atas penyakit COVID-19 yang bisa ditularkan dari manusia ke manusia (Long et al., 2020).

Penyakit coronavirus 2019 (COVID-19) merupakan penyakit yang menyerang pernapasan dikenal sebagai infeksi saluran napas yang parah atau sindrom pernapasan akut coronavirus 2 (SARS-CoV-2) mempunyai kemiripan filogenetik dengan SARS-CoV (Fadli, 2020). Sebagian besar pasien menderita COVID-19 memiliki gejala klinis termasuk demam, batuk kering, sakit tenggorokan dan kelelahan (Wu \& McGoogan, 2020). Statistik penyebaran virus corona pada bulan Juni 2020 di Indonesia telah dikonfirmasi sebanyak 43.803 kasus dan 2373 kematian, sedangkan dari data seluruh dunia ada 8.453.080 kasus dan 452.520 kematian. Untuk dapat mendeteksi penyakit COVID-19 pada umumnya dilakukan secara klinis melalui pemeriksaan gejala fisik (Chen et al., 2020).

Selain itu, bisa didiagnosa lewat foto rontgen, MRI dan CT-Scan. Di saat pandemi ini, para dokter dari berbagai spesialis dan petugas kesehatan melakukan pengambilan foto rontgen sehingga bisa memecahkan dan menganalisis citra 
supaya bisa mendiagnosis dan juga mengevaluasi penyakit khususnya COVID-19 (Lin et al., 2020).

Hasil dari citra rontgen biasanya terlihat kabur, kontras yang rendah dan lain-lain, sehingga mengakibatkan perbedaan dalam membaca citra. Selanjutnya, hasil visualisasi citra yang kurang bagus karena redaman sinar- $\mathrm{X}$ yang berbeda-beda antara kelenjar pada jaringan normal dan yang terkena penyakit COVID-19 (Pereira et al., 2020).

Maka untuk mengatasi permasalahan itu digunakan suatu pengolahan citra guna meningkatkan kualitas foto rontgen. Pengolahan citra dengan komputer berperan penting untuk meningkatkan kualitas citra lebih jelas. Operasi saat mengolah citra salah satunya memperkenalkan citra secara digital disajikan dalam gambar yang disebut segmentasi (Rahmadewi, 2016). Segmentasi merupakan proses pembagian pada citra dalam beberapa kelompok di tempat sesuai ciri khas masing-masing yang bertujuan untuk menemukan ciri-ciri khusus yang ada di citra. Segmentasi ini juga sebagai proses memisahkan suatu tempat atau wilayah dalam citra, yang mana di wilayah tersebut memiliki intensitas, warna dan tekstur yang sama pula (Öztürk \& Akdemir, 2015). Objek yang disegmentasi pada citra bisa melakukan pemisahan daerah objek dengan latar belakangnya, kemudian setelah segmentasi pada daerah objek bisa diambil informasi dari citra tersebut (Hakim \& Fitria, 2019).

Deteksi tepi (Edge Detection) pada citra merupakan sebuah proses guna mendapatkan hasil tepi-tepi dari citra, yang bertujuan untuk menandai suatu bagian yang dijadikan sebagai detail citra (Rahmadewi \& Kurnia, 2016). Selain itu, deteksi ini untuk menampilkan garis batas secara maksimal dalam sebuah citra dan juga bisa menghasilkan tepi-tepi dari objek gambar. Suatu titik $(\mathrm{x}, \mathrm{y})$ dapat dikatakan sebagai tepi (edge) dari suatu citra apabila titik memiliki perbedaan yang sangat jelas dari sekelilingnya (Kuswandi \& Fadillah, 2019). Pada penelitian yang kami buat ini menggunakan metode sobel untuk deteksi tepi citra. Metode sobel merupakan metode yang dikembangkan dari metode robert dengan memakai filter High Pass Filter (HPF) menggunakan operator sobel (Zalukhu, 2016).

Penelitian kami mengacu pada penelitianpenelitian sebelumnya, berikut ini beberapa penelitian mengenai deteksi tepi metode sobel berjudul "Klasifikasi Penyakit Paru Berdasarkan Citra Rontgen Dengan Metoda Segmentasi Sobel" oleh Reni Rahmadewi dan Rahmadi Kurnia, membahas simulasi pada klasifikasi penyakit paru menggunakan segmentasi sobel dalam citra rontgen. Hasil penelitian berupa perbandingan piksel terhadap hasil uji deteksi daerah paru-paru disertai interval persentase jenis penyakit yang menyerangnya (Rahmadewi \& Kurnia, 2016).

Penelitian berikutnya berjudul "Analisis Intensitas Metode Pendeteksian Tepi Sobel" oleh Erick Wijaya, membahas penggunaan kernel yang dirubah pada deteksi tepi sobel, sehingga mengubah nilai intensitasnya, sehingga hasil penelitian berupa mendapat metode deteksi tepi yang mana nilai intensitas bisa diatur sesuai kebutuhan (Wijaya, 2012). Penelitian selanjutnya berjudul "Segmentasi Region of Interest (ROI) Garis Telapak Tangan Menggunakan Deteksi Tepi Sobel" oleh Khoilil Fitriya dan Hakim, membahas akurasi metode segmentasi ROI dengan mendeteksi tepi sobel di citra garis telapak tangan, hasil penelitiannya penggunaan deteksi tepi sobel pada citra garisnya bisa disegmentasi dengan baik dengan akurasi tertinggi dibanding metode lainnya (Hakim \& Fitria, 2019).

Penelitian kami juga akan membahas bagaimana bisa menerapkan metode sobel untuk dapat mendeteksi tepi dengan teknik thresholding dalam aplikasi Matlab R2013b versi 8.2 dengan No. Lisensi 724504 terhadap sample rontgen citra COVID-19, sehingga bisa mengidentifikasinya lebih lanjut. Deteksi tepi mempunyai batas diantaranya dua daerah (region) yang punya perbedaan pada gray level. Sebagian besar proses deteksi tepi berdasarkan pada perhitungan local derivative operator. Citra bisa ditelusuri baik secara vertikal ataupun horizontal dan mengamati adakah warna yang berubah yang melampui sensifitas diantara dua titik yang saling berdekatan (Bharodiya \& Gonsai, 2019).

Tujuan dari penelitian ini untuk membuat simulasi pada citra rontgen COVID-19 dan mengetahui daerah infeksi virus tersebut menggunakan metode sobel. Alasan penggunaan metode sobel pada penelitian ini karena mempunyai keunggulan dalam menyelesaikan perhitungan dengan mudah dan menghasilkan citra yang mudah terbaca dibanding dengan beberapa metode lainnya (Rahmadewi, 2016). Adapun manfaat yang diperoleh dari penelitian ini agar hasil citra yang jelas, sehingga dapat membaca citra rontgen COVID-19 dengan teliti dan terbukti kebenarannya, kemudian bisa memahami dan menambah ilmu pengetahuan terutama deteksi tepi menggunakan metode sobel (Amelia \& Marwanti, 2013). 


\section{Metode}

Pada penelitian ini dengan metode penelitian kuantitatif eksperimen. Metode tersebut merupakan metode yang memiliki sifat menguji pengaruh satu variabel maupun beberapa variabel terhadap variable lainnya. Pemeriksaan penyakit COVID-19 berdasarkan hasil citra rontgen. Dalam metode pengumpulan data, penulis menggunakan teknik studi kepustakaan dengan mempelajari karya ilmiah, artikel dan jurnal, kemudian teknik penulisan pada penelitian ini, penulis berpedoman pada beberapa jurnal dan referensi penelitian yang mendukung penelitian ini (Sutiyono, 2017).

Adapun sampel citra rontgen COVID-19 berjumlah 13 sampel yang diambil dari situs database yang dirilis secara publik dan bebas digunakan. Sumber ini dimanfaatkan untuk mendapatkan sampel citra tersebut yang selanjutnya digunakan untuk membedakan hasil deteksi tepi metode sobel dan menganalisa penyakit COVID-19 pada masing-masing sampel citra, sehingga dibutuhkan banyak sampel citra tersebut (GitHub, 2020).

Deteksi tepi metode sobel pada citra rontgen COVID-19 dengan cara menghitung ruang pada citra kemudian difilter High Pass Filter (HPF) dengan operator sobel sehingga, terlihat daerahdaerah mempunyai nilai tinggi yang menandai deteksi tepi dari citra sehingga terlihat penyebaran infeksi yang diakibatkan oleh coronavirus berupa cairan hidrokarbon yang menyelimuti di bagian bawah paru-paru terutama alveolus, sehingga paruparu terlihat kabur atau tidak jelas dan tampak berwarna putih pada penderita COVID-19 (Rahmadewi, 2016).

Berkaitan dengan perbaikan kualitas citra dengan filter high pass filter pada metode sobel merupakan proses yang mengawali pengolahan citra. Perbaikan kualitas dilakukan karena biasanya citra yang telah diuji memiliki kualitas yang kurang baik, contohnya citra yang ada derau (noise) ketika pengiriman melewati saluran transmisi, citra kurang tajam, terlihat kabur, citra terlalu gelap ataupun terang dan lain sebagainya. Dalam perbaikan kualitas citra memakai stretching contras dan modifikasi histogram (Sari, 2016).

Penggunaan stretching contras karena mempunyai penyebaran nilai kontras yang lebar dan tidak gelap maupun terlalu terang pada citra hasil perbaikan, kemudian modifikasi histogram dilakukan karena bisa melembutkan dengan filter high pass filter menyebabkan noise menghilang ketika proses segmentasi (Wang, 2018).
Noise bisa diartikan gangguan yang ada pada citra karena penyimpanan data digital yang diterima oleh alat penerima data citra, sehingga mengganggu kualitas citra. Penyebab noise bisa terjadi karena gangguan fisik (optik) di alat penangkap citra, contoh kotoran, debu yang menempel di lensa foto ataupun proses pengolahan citra yang tidak sesuai prosedur (Shui, 2012).

Parimeter deteksi tepi menggunakan metode sobel dalam perhitungan matlab sebagai berikut :

Pada pengaturan piksel di sekeliling piksel $(\mathrm{x}, \mathrm{y})$,

$$
\left[\begin{array}{ccc}
a_{0} & a_{1} & a_{2} \\
a_{7} & (x, y) & a_{3} \\
a_{6} & a_{5} & a_{4}
\end{array}\right]
$$

Operator sobel adalah magnitude dari gradien bisa dihitung menggunakan,

$$
M=\sqrt{s_{x}^{2}+s_{y}^{2}}
$$

Turunan parsial bisa dihitung dengan,

$$
\begin{aligned}
& S_{x}=\left(a_{2}+c a_{3}+a_{4}\right)-\left(a_{0}+c a_{7}+a_{6}\right) \\
& S_{y}=\left(a_{0}+c a_{1}+a_{2}\right)-\left(a_{6}+c a_{5}+a_{4}\right)
\end{aligned}
$$

Dengan menggunakan konstanta c adalah 2, berbentuk mask, $s_{x}$ dan $s_{y}$ bisa dinyatakan,

$$
s_{x}=\left[\begin{array}{lll}
-1 & 0 & 1 \\
-2 & 0 & 2 \\
-1 & 0 & 1
\end{array}\right] \quad s_{y}=\left[\begin{array}{ccc}
1 & 2 & 1 \\
0 & 0 & 0 \\
-1 & -2 & -1
\end{array}\right](5)
$$

Menghitung arah tepi menggunakan persamaan,

$$
A(x, y)=\tan ^{-1}\left(S_{x} / S_{y}\right)
$$

Penggunaan aplikasi yaitu Matlab R2013b versi 8.2 dan sampel citra yang digunakan memiliki format jpeg (*jpg). Joint-Photographic Experts Group (JPEG) adalah sebuah kelompok yang merancang sebuah algoritma kompresi citra lossy. JPEG lebih dikenal secara umum sebagai salah satu format ekstensi penyimpanan citra (“.jpg) (Masatu, 2014).

Dalam penelitian ini teknik kompresi citra menggunakan JPEG 2000 didesain untuk medical imegrey, foto digital dan scanning. Kompresi ini merupakan pengembangan teknik kompresi JPEG yang mana JPEG 2000 menggunakan teknologi Wavelet transform. Tujuan kompresi JPEG 2000 untuk menyimpan data yang digunakan dalam representasi digital dengan ukuran sekecil mungkin dengan tetap mempertahankan detail visualnya. JPEG 2000 mempunyai performa lebih baik 
dibandingkan dengan JPEG terutama lebih fleksible dalam codestream-nya (Suia, 2019).

Keunggulan JPEG 2000 diantaranya memberikan hasil data kompresi yang lebih kecil tetapi bisa memenuhi syarat untuk digunakan, kemudian transmisi progresif dan akurasi serta resolusi pixel tinggi, setelah itu dapat digunakan pada bit-rate rendah untuk network image dan remote sensing, lalu menggunakan Region of Intersest (ROI), lalu Robustness to bit error yang digunakan untuk komunikasi jaringan dan wireless, selanjutnya mendukung protective image security (watermaking, labeling, stamping dan encryption), mendukung image ukuran besar (size 64k x 64k, size up to $232-1$ ), mendukung mata data yang baik untuk computer-generated imaginary (Suia, 2019). Dengan menggunakan JPEG 2000 bisa mengurangi kekurangan atau kelemahan yang ada pada JPEG. Pada JPEG 2000 diperlukan mengatasi antara lain (Masatu, 2014) :

1. Kompresi Low bit-rate dibawah 0,25 bpp dimana JPEG tidak menyediakan.

2. Kompresi Lossless and lossy compression dalam satu codestream.

3. Kompresi citra yang berukuran lebih dari 64 x 64 tetap menggunakan proses pemisahan citra ke dalam bagian-bagian (tiling).

Untuk diagram alir sekaligus simulasi yang bisa dilakukan terdapat pada Gambar 1 seperti (Rahmadewi, 2016) :

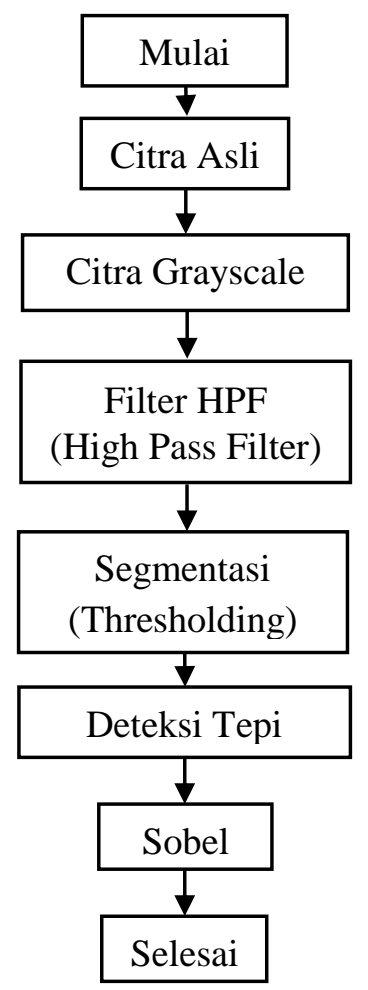

Gambar 1. Diagram alir penelitian
Untuk prosedur kerja pada penelitian ini diantaranya :

1. Membuat rancangan komponen GUI (Graphical User Interface) yang berguna untuk mengolah citra.

2. Menentukan file yang akan dibuat sebagai sampel citra.

3. Menulis kode pemograman untuk proses mengolah citra, yaitu :

a. Citra asli diubah ke citra grayscale, dengan persamaan,

$$
\text { Grayscale }=\frac{R+G+B}{3}
$$

b. Citra hasil grayscale difilter dengan high-pass-filtering.

c. Citra disegmentasi menggunakan metode thresholding dengan menentukan nilai ambang terlebih dahulu. Cara menentukan nilai ambang dengan menentukan pilihan pada perkiraan awal threshold $\left(\mathrm{T}_{0}\right) \quad$ kemudian, segmentasi dengan nilai $\mathrm{T}$. setelah itu rata-rata segmentasi atau intensitas ( $\mu 1$ dan $\mu 2)$ dihitung pada setiap piksel, setelah itu hitung nilai $\mathrm{T}$ yang baru dari penjumlahan nilai rata-rata intensitas dibagi dua, yaitu :

$T=\frac{1}{2}(\mu 1+\mu 2)$

d. Citra hasil thresholding ditajamkan dengan deteksi tepi menggunakan operator sobel.

e. Setelah muncul hasil citra sobel, maka program ditutup.

\section{Hasil dan Pembahasan}

Penggunaan aplikasi Matlab digunakan dalam pengujian terhadap citra rontgen COVID-19 hanya membatasi citra berwarna hitam dan putih (gray level). Citra asli diubah ke dalam citra grayscale, kemudian citra tersebut difilter lalu dithreshold dengan nilai ambang batas (T), selanjutnya dideteksi menggunakan deteksi tepi operator sobel untuk melihat dengan jelas penyebaran penyakit COVID-19. 
Tabel 1.Hasil segmentasi citra metode sobel pada Penderita COVID-19

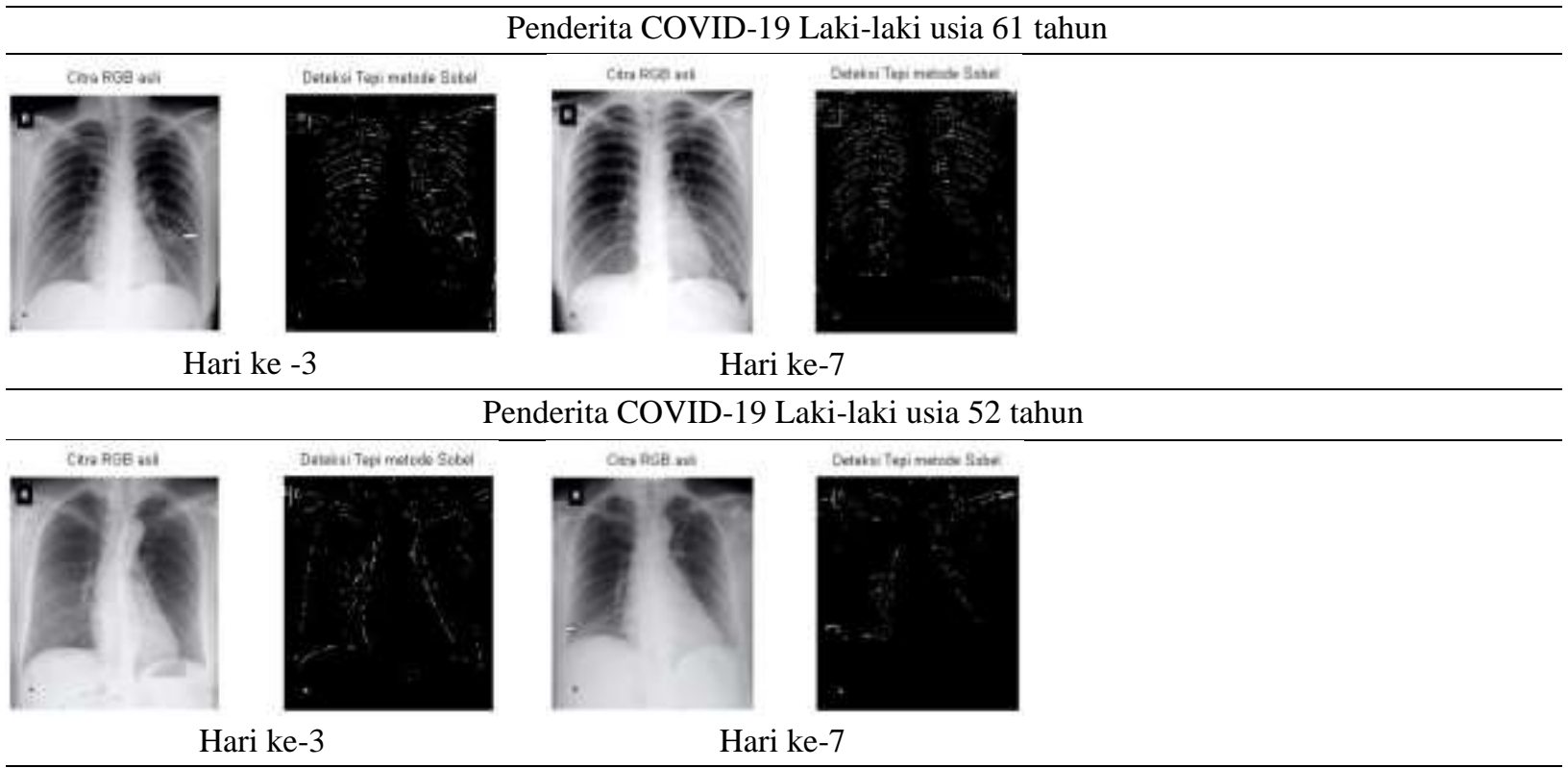

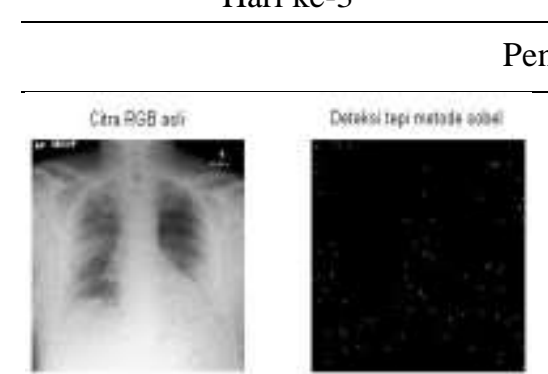

Hari ke-6

Penderita COVID-19 Perempuan usia 24 tahun

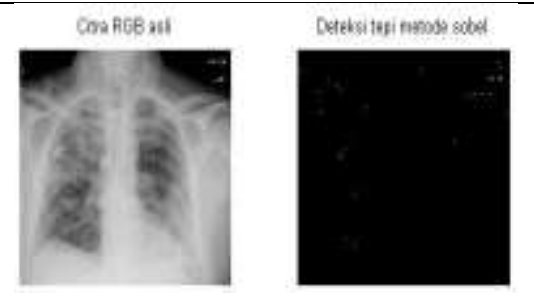

Hari ke-7

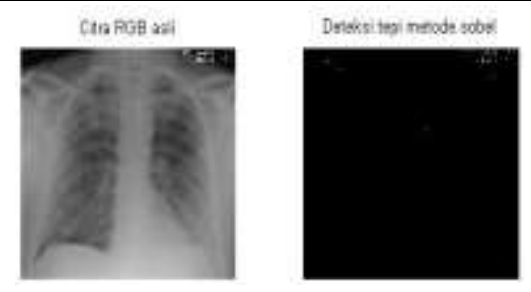

Hari ke-12

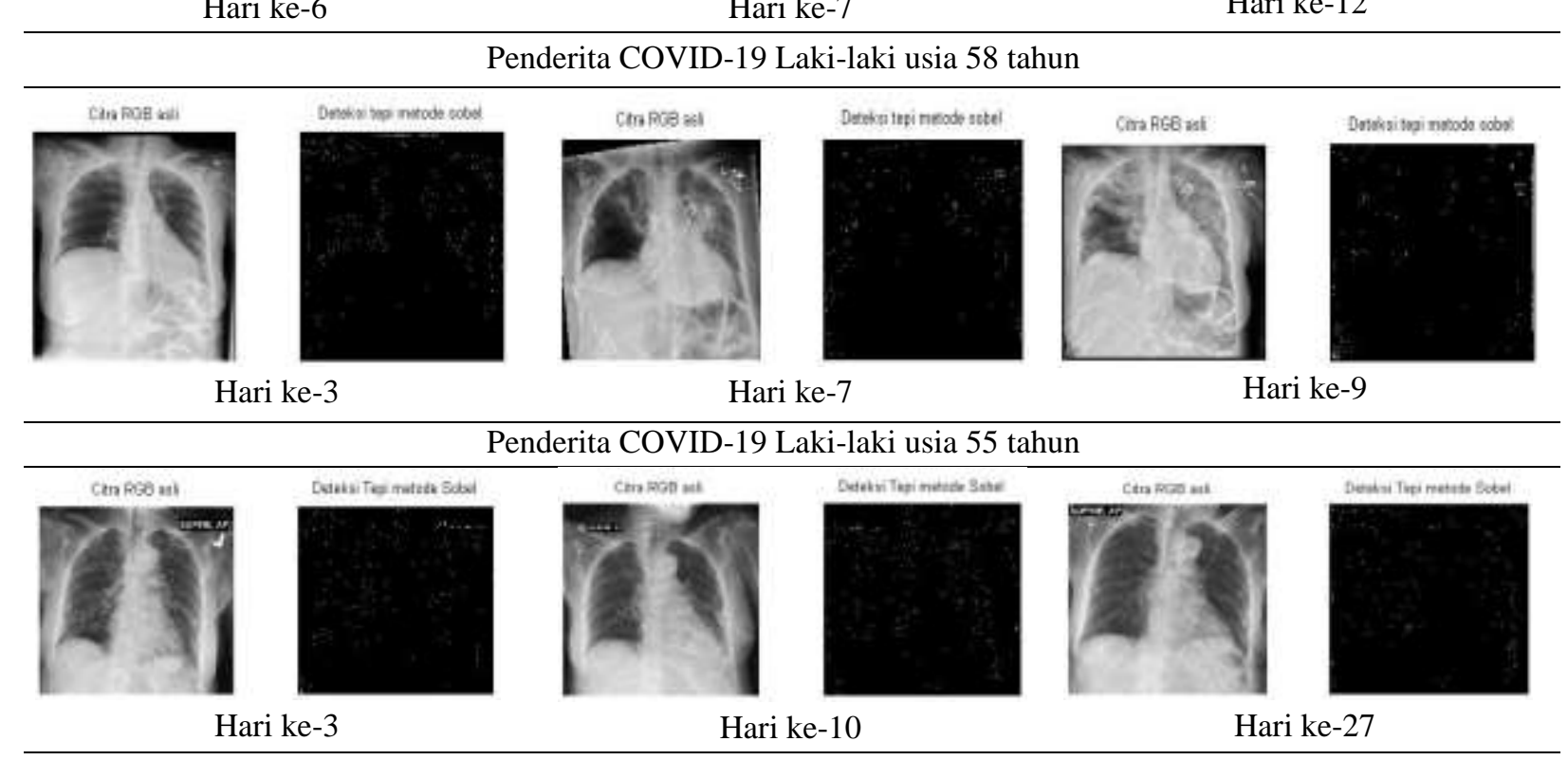

Pengujian yang telah dilakukan pada hasil citra rontgen COVID-19 menggunakan metode sobel. Disini akan dianalisa proses deteksi tepi metode sobel pada citra digital. operator sobel juga dipakai dalam mencari gradien dari piksel-piksel pada citra yang sebelumnya sudah digrayscale maka, diperlukan kernel konvolusi pada matriks berukuran 3x3 yang bernilai vertikal dan horizontal pada kernel sobel. Kernel sobel menempatkan pembobotan pada piksel-piksel sesuai letaknya terhadap perhitungan gradien. Hal ini gradien merupakan hasil suatu pengukuran pada fungsi intensitas yang berubah. Nilai yang tersusun pada pembobotan memperlihatkan gradien termasuk 
penggabungan dua posisi, yaitu garis lintang dan bujur (Wijaya, 2012)

Untuk itu bisa menggunakan gradien $G(x, y)$ yaitu vektor yang terdiri atas dua unsur antara lain Gx dan Gy. Pada saat deteksi tepi dilakukan dengan cara membaca piksel dari kiri atas kemudian bergerak ke kanan bawah, sehingga untuk memudahkan penelusuran tepi, perhitungan masing-masing gradien Gx dan Gy menggunakan matriks metode sobel mask $3 \times 3$ sebagai berikut (Zalukhu, 2016) :

\begin{tabular}{|l|l|l|}
\hline-1 & 0 & +1 \\
\hline-2 & 0 & +2 \\
\hline-1 & 0 & +1 \\
\hline
\end{tabular}

Gx

\begin{tabular}{|c|c|c|}
\hline+1 & +2 & +1 \\
\hline 0 & 0 & 0 \\
\hline-1 & -2 & -1 \\
\hline
\end{tabular}

\section{Gy}

Adapun kelebihan metode sobel adalah mampu mengurangi noise ketika sebelum perhitungan deteksi tepi, sehingga memudahkan perhitungannya, lalu hasil citra yang jelas terbaca (Maharani \& Apriyani, 2013).

Pemeriksaan dari citra rontgen masing-masing pasein penderita COVID-19 sehingga bisa mendiagnosis infeksi dari coronavirus yang menyerang tubuh terutama organ paru-paru, selain itu juga adanya pengendapan suatu cairan disekitarnya untuk diambil tindakan lebih lanjut (Mardhiyah, 2013). Tujuan dari penelitian ini adalah untuk melakukan simulasi dengan operator sobel pada saat segmentasi pada citra yang dilanjutkan dengan deteksi tepi dan mengetahui posisi paru-paru mana yang terinfeksi coronavirus yang tentunya jelas hasil thresholding tersebut, sehingga memberikan informasi penyebaran penyakit COVID-19 (Strunk et al., 2014).

Pada infeksi COVID-19 terjadi peradangan rongga udara yang disebabkan oleh coronavirus berakibat adanya cairan hidrokarbon yang memenuhi ruang di paru-paru. Pada kenyataannya citra rontgen paru-paru yang sehat berwarna hitam sedangkan, citra rontgen COVID-19 terdapat bercak-bercak putih terlihat kabur dan tidak merata yang menghalangi paru-paru, sehingga daerah yang berwarna putih tersebut telah dinfeksi oleh coronavirus (Sun et al., 2020). Pada kasus COVID19, coronavirus menginfeksi pada laki-laki dan perempuan mulai usia 18 sampai 65 tahun dan jumlah terinfeksi paling banyak adalah laki-laki. Untuk seseorang berjenis kelamin laki-laki lebih rentan terkena coronavirus dari pada perempuan karena laki-laki mempunyai kadar enzyme 2 (ACE 2) lebih banyak dan tertinggi dibandung perempuan. Enzim ini yang mengakibatkan lakilaki lebih mudah terinfeksi virus maupun penyakit dan punya komplikasi yang parah (kritis) jika terinfensi dari pada perempuan (Lawton, 2020).

Perlu diketahui bahwa enzyme 2 (ACE 2) adalah reseptor berada di permukaan sel yang akan berikatan dengan virus baru yaitu coronavirus bisa masuk dan menginfeksi sel (Oudit \& Pfeffer, 2020). Keberadaan enzim ini terdapat pada paruparu, jantung, ginjal dan kadar sangat tinggi berada di testis dan juga sel epitel yang terlihat seperti infeksi saluran nafas (Damman et al., 2014). Selain pengaruh enzyme 2 (ACE 2), ada juga faktor lain yaitu faktor periku seperti kebiasaan merokok dan malas mencuci tangan karena merokok bisa meningkatkan penyakit jantung dan paru-paru serta mengganggu sel imun sehingga berdampak pada infeksi COVID-19 (Di Gennaro et al., 2020).

Berkaitan dengan sistem kekebalan tubuh (imunitas) pada perempuan berdampak lebih signifikan dari pada laki-laki karena perempuan mempunyai dual kromosom $X$ per sel sedangkan laki-laki hanya memiliki satu kromosom $\mathrm{X}$ per sel saja. Fakta menunjukkan ada beberapa gen kekebalan yang penting berada di kromosom $\mathrm{X}$ terutama gen protein yang mampu mendeteksi RNA pada coronavirus dan juga hormon estrogen dan progesteron pada perempuan bisa meningkatkan kekebalan tubuhnya, sehingga sel imun merespon adanya coronavirus di perempuan lebih baik dari pada laki-laki (Sama et al., 2020).

Hasil penelitian ini bisa dilihat di Tabel 1 yang mana sebelah kiri merupakan citra asli sedangkan sebelah kanan merupakan citra hasil deteksi tepi metode sobel. Daerah segmentasi deteksi tepi tersebut ditandai dengan titik-titik dan garis tepi warna putih.

Pada Tabel 1, hasil citra rontgen COVID-19 pasien laki-laki berumur 61 tahun dilakukan pemeriksaan rontgen toraks pada hari ke-3 menunjukkan penyebaran coronavirus terdapat di paru-paru begitu signifikan meluas, sehingga lebih banyak deteksi tepi sedangkan, hari ke-7, memperlihatkan penyebarannya mulai melambat, maka deteksi tepi semakin sedikit. Begitu pula, hasil citra rontgen COVID-19 pasien laki-laki berumur 52 tahun dilakukan pemeriksaan rontgen toraks pada hari ke-3, adanya penyebaran coronavirus yang begitu cepat meluas, sehingga lebih banyak deteksi tepi sedangkan, hari ke-7 terlihat penyebarannya yang lambat, maka deteksi tepi semakin sedikit pula. 
Pada hasil citra rontgen COVID-19 pasien perempuan berumur 24 tahun dilakukan pemeriksaan rontgen toraks pada hari ke- 6,7 dan 12 menunjukkan semakin bertambah hari, maka deteksi tepi semakin sedikit, bercak-bercak putih berkurang, lalu paru-paru kembali normal karena penyebaran coronavirus mulai melambat dan lamakelamaan akan hilang dari paru-paru dan kondisi badan membaik. Begitu pula, hasil citra rontgen COVID-19 pasien laki-laki berumur 58 tahun dilakukan pemeriksaan rontgen toraks pada hari ke-3, 7 dan 9 memperlihatkan semakin bertambah hari, maka deteksi tepi tidak begitu tampak. Pada hasil citra rontgen COVID-19 pasien laki-laki berumur 55 tahun dilakukan pemeriksaan rontgen toraks pada hari ke-3, 10 dan 27 menggambarkan semakin bertambah hari, maka deteksi tepi tidak terlihat pula.

Setelah semua sampel diuji menggunakan metode sobel, maka hasilnya ada batas tepi berupa titik maupun garis tepi bisa terbaca dan citra terlihat lebih jelas di setiap sampel, selain itu, dengan metode sobel menghasilkan piksel warna putih yang begitu terlihat pula. Segmentasi menggunakan metode sobel pada penelitian ini mampu melakukan segmentasi citra yang baik dan akurat, sesuai hasil penelitian yang dilakukan oleh Khoilil Fitriya dan Hakim berjudul "Segmentasi Region of Interest (ROI) Garis Telapak Tangan Menggunakan Deteksi Tepi Sobel" (Hakim \& Fitria, 2019).

Hasil deteksi tepi metode sobel dari Tabel 1 sampai 5 pada rontgen citra COVID-19 bahwa semakin bertambah hari, maka deteksi tepi citra semakin berkurang, yang ditandai pada warna putih sebagai daerah infeksi oleh coronavirus, sehingga dominan warna hitam yang merupakan paru-paru sehat dan tidak ada coronavirus. Hal ini penyebaran coronavirus pada area paru-paru semakin menurun. Selain itu, hasil tersebut juga bisa bisa memperlihatkan paru-paru yang bermasalah, dari kejelasan hasil thresholdingnya, sehingga dengan hasil ini memberikan banyak informasi yang berkaitan penyakit COVID-19, maka hasil yang didapat sesuai pada penelitian yang dilakukan oleh Reni Rahmadewi berjudul "Analisa Perbandingan Beberapa Metode Deteksi Tepi Pada Citra Rontgen Penyakit Paru-Paru" (Rahmadewi, 2016). Hasil penelitian ini membuktikan metode sobel merupakan metode yang paling bagus sehingga, memudahkan identifikasi penyakit COVID-19.
Pengujian pada hasil segmentasi untuk penyebaran penyakit COVID-19 dalam citra rontgen bisa dilihat dengan teknik thresholding, sehingga terlihat tepi suatu objek yang lebih jelas. Sebelum segmentasi, maka citra harus difilter dengan high-pass filter menggunakan metode sobel, sehingga menghasilkan deteksi tepi yang bisa memberikan informasi tentang daerah yang terinfeksi COVID-19. Hal ini menunjukkan bahwa deteksi tepi menggunakan metode sobel bisa menjadi salah satu acuan dalam pemeriksaan citra rontgen penyakit COVID-19.

Pada kesempatan kali ini ucapan terimakasih kepada pihak-pihak yang telah merelakan waktu, pikiran dan tenaga yang membantu dalam penyelesaian penelitian ini.

\section{Daftar Pustaka}

Amelia, L., \& Marwanti, R. (2013). Perbandingan Metode Roberts Dan Sobel Dalam Mendeteksi Tepi Suatu Citra Digital. 1, 1-16.

Bharodiya, A. K., \& Gonsai, A. M. (2019). An improved edge detection algorithm for X-Ray images based on the statistical range. Heliyon, 5(10), pp.e02743.

Chen, H., Ai, L., Lu, H., \& Li, H. (2020). Clinical and imaging features of COVID-19. Radiology of Infectious Diseases, April, 1-8.

Damman, K., Valente, M. A. E., Voors, A. A., O'Connor, C. M., Van Veldhuisen, D. J., \& Hillege, H. L. (2014). Renal impairment, worsening renal function, and outcome in patients with heart failure: An updated metaanalysis. European Heart Journal, 35(7), 455-469.

Di Gennaro, F., Pizzol, D., Marotta, C., Antunes, M., Racalbuto, V., Veronese, N., \& Smith, L. (2020). Coronavirus diseases (COVID-19) current status and future perspectives: A narrative review. International Journal of Environmental Research and Public Health, 17(8).

Fadli. (2020). Mengenal Covid-19 dan Cegah Penyebarannya dengan "Peduli Lindungi" Aplikasi Berbasis Andorid. Program Studi Teknik Elektro, Universitas Jenderal Sudirman.

GitHub. (2020). Covid-19 Chest X-ray. https://github.com/ieee8023/covid-chestxraydataset [Accessed on May 21, 2020 at 02.09 $\mathrm{PM}]$

Hakim, L., \& Fitria, K. (2019). Segmentasi Region Of Interest (ROI) Garis Telapak Tangan Menggunakan Deteksi Tepi Sobel. Explore 
IT: Jurnal Keilmuan Dan Aplikasi Teknik Informatika, 11(1), 29-40.

Kuswandi, E. R., \& Fadillah, N. (2019). Perbandingan Metode Robert dan Metode Prewitt untuk Deteksi Tepi pada Citra Tanda Tangan. InfoTekJar (Jurnal Nasional Informatika Dan Teknologi Jaringan), 3(2), 155-158.

Lawton, G. (2020). Men hit harder by covid-19. New Scientist, 246(3279), 8.

Lin, X., Gong, Z., Xiao, Z., Xiong, J., Fan, B., \& Liu, J. (2020). Novel coronavirus pneumonia outbreak in 2019: Computed tomographic findings in two cases. Korean Journal of Radiology, 21(3), 365-368.

Long, C., Xu, H., Shen, Q., Zhang, X., Fan, B., Wang, C., Zeng, B., Li, Z., Li, X., \& Li, H. (2020). Diagnosis of the Coronavirus disease (COVID-19): rRT-PCR or CT? European Journal of Radiology, 126(February), 108961.

Maharani, D. S., \& Apriyani. (2013). Perbandingan Metode Sobel, Metode Prewitt dan Metode Robert Untuk Deteksi Tepi Objek Pada Aplikasi Pengenalan Bentuk Berbasis Citra Digital. 1-7.

Mardhiyah. (2013). Metode Segmentasi Paru-paru dan Jantung Pada Citra X-Ray Toraks. IJEIS (Indonesian Journal of Electronics and Instrumentation Systems), 1(2), 35-44.

Masatu, D. A. (2014). Penerapan Algoritma Kompresi JPEG dan Metode Fuzzy C-Means pada Kompresi Citra Berbasis Entropi. Jurnal Penelitian Teknik Elektro dan Teknologi Informasi, 1(1), 8.

Sutiyono, P. A., (2017). Menganalisa Perbandingan Deteksi Tepi antara Metode Sobel dan Metode Robet, Program Studi Teknik Informatika, Fakultas Ilmu Komputer, Universitas Dian Nuswantoro Semarang.

Oudit, G. Y., \& Pfeffer, M. A. (2020). Plasma angiotensin-converting enzyme 2: novel biomarker in heart failure with implications for COVID-19. European Heart Journal, 1818-1820.

Öztürk, Ş., \& Akdemir, B. (2015). Comparison of Edge Detection Algorithms for Texture Analysis on Glass Production. Procedia Social and Behavioral Sciences, 195(July), 2675-2682.

Pereira, R. M., Bertolini, D., Teixeira, L. O., Silla, C. N., \& Costa, Y. M. G. (2020). COVID-19 identification in chest $\mathrm{X}$-ray images on flat and hierarchical classification scenarios. Computer Methods and Programs in
Biomedicine, 105532.

Rahmadewi, R. (2016). Analisa Perbandingan Beberapa Metode Deteksi Tepi Pada Citra Rontgen Penyakit Paru - Paru. Media Elektro, VI(1), 9-12.

Rahmadewi, R., \& Kurnia, R. (2016). Klasifikasi Penyakit Paru Berdasarkan Citra Rontgen dengan Metoda Segmentasi Sobel. Jurnal Nasional Teknik Elektro, 5(1), 7.

Sama, I. E., Ravera, A., Santema, B. T., van Goor, H., Ter Maaten, J. M., Cleland, J. G. F., Rienstra, M., Friedrich, A. W., Samani, N. J., Ng, L. L., Dickstein, K., Lang, C. C., Filippatos, G., Anker, S. D., Ponikowski, P., Metra, M., van Veldhuisen, D. J., \& Voors, A. A. (2020). Circulating plasma concentrations of angiotensin-converting enzyme 2 in men and women with heart failure and effects of renin-angiotensinaldosterone inhibitors. European Heart Journal, 31, 1810-1817.

Sari, H. L. (2016). Analisa Perbandingan Metode Filter Gaussian, Mean Dan Median Terhadap Reduksi Noise. J. Media Infotama, 12(1), 2130.

Shui, P. L., \& Zhang, W. C. (2012). Noise-robust edge detector combining isotropic and anisotropic Gaussian Kernels. Pattern Recognit, 45(2), 806-820.

Strunk, J. L., Temesgen, H., Andersen, H., \& Packalen, P. (2014). Imaging Profile of the COVID-19 Infection: Radiologic Findings and Literature Review Authors: 80(2), 1-8. https://doi.org/10.14358/PERS.80.2.000

Suia, D. (2019). Analisis Kualitas Citra Medis Terkompresi JPEG. Majalah Ilmiah Teknologi Elektro, 18(2), 235-239.

Sun, R., Liu, H., \& Wang, X. (2020). Mediastinal Emphysema, Giant Bulla, and Pneumotoraks Developed during the Course of COVID-19 Pneumonia. Korean Journal of Radiology, 21(5), 541-544.

Wang, J. W., \& Lin, W. C. (2018). Edge detection in medical images with quasi high-pass filter based on local statistics. Biomed. Signal Process. Control, 39, 294-302.

Wijaya, E. (2012). Analisis Intensitas Metode Pendeteksian Tepi Sobel. Analisis Intensitas Metode Pendeteksian Tepi Sobel, 1(1), 2527.

Wu, Z., \& McGoogan, J. M. (2020). Characteristics of and Important Lessons from the Coronavirus Disease 2019 (COVID19) Outbreak in China: Summary of a Report of 72314 Cases from the Chinese Center for 
Disease Control and Prevention. JAMA -

Journal of the American Medical Association, 323(13), 1239-1242.

Zalukhu, A. (2016). Implementasi Metode Canny

Dan Sobel Untuk Mendeteksi Tepi Citra.

Jurnal Riset Komputer (JURIKOM), 3(6), $25-29$. 